Acta vet. scand. $1978,19,129-132$.

From the State Veterinary Laboratory for Northern Norway, Harstad.

\title{
A CASE OF MULTIPLE CUTANEOUS MALIGNANT LYMPHOMA IN REINDEER, PROBABLY OF IMMUNOLOGIC-PARASITIC ORIGIN
}

\author{
By \\ Knut Kummeneje and Trygve T. Poppe
}

KUMMENEJE, K. and T. T. POPPE: A case of multiple cutaneous malignant lymphoma in reindeer, probably of immunologic-parasitic origin. Acta vet. scand. 1978, 19, 129-132. - In a reindeer herd brought in for slaughter in February 1977 in Finnmark county, one animal about $1 \frac{1}{2}$ years old, was found to have about 20 hairless nodules, each about $5 \mathrm{~cm}$ in diameter, in the skin. The nodules were of discoid shape and well demarcated, and made only slight impressions in the underlying muscles. They were found to be neoplasms, and should probably be classified as a malignant lymphoma of histiocytic type (Smith et al. 1972). Metastases were found in the prescapular lymph nodes. The animal was well-fed and without clinical signs of general disease. The distribution of the nodules and the absence of subcutaneous larvae of the very common reindeer grub fly (Oedemagena tarandi) led to the conclusion that the condition was most probably a result of a pathological immune reaction to parasitic larvae.

reindeer; neoplasia; lymphoma; histiocytic type; Oedemagen a tarandi.

Neoplasia in reindeer is seldom reported. This may be due to either a low incidence of neoplasms in this animal, or inadequate registration. Disease registration among free-living animals is often a difficult task compared to that among domestic animals. During the last 10 years, small numbers of neoplasms from reindeer have been examined at this laboratory. In this material, fibroma, bile duct carcinoma, carcinoma (in cavum nasi) and adenocarcinoma have been identified.

This report describes a multiple cutaneous malignant lymphoma in a reindeer, most probably caused by parasitic fly larvae. 


\section{MATERIALS AND METHODS}

In a reindeer herd brought in for slaughter in February 1977 in Finnmark county, one animal about 11/2 years old, was found to have about 20 hairless nodules in the skin on the back. The animal was well nourished and did not show any clinical signs of general disease. Infection with larvae of the very common reindeer grub fly (Oedemagena tarandi) was not observed, while the rest of the flock was infected as usual. The distribution of the nodules on the back was similar to that which could be expected for larvae of $O$. tarandi.

At slaughter both the prescapular lymph nodes were found to be enlarged. No other pathological changes were observed in addition to the skin nodules. After slaughter, samples of the skin nodules, the liver, a prescapular lymph node and a muscle sample were examined at this laboratory.

Samples for histology were fixed in $10 \%$ formalin and stained by the usual methods, including silver impregnation according to Gomori.

\section{RESULTS}

Macropathology. The nodules were about $5 \mathrm{~cm}$ in diameter and of regular discoid shape with a brownish-grey central area. They were well demarcated and made only slight impressions in the underlying muscles (Figs. 1 and 2). The cut surface was
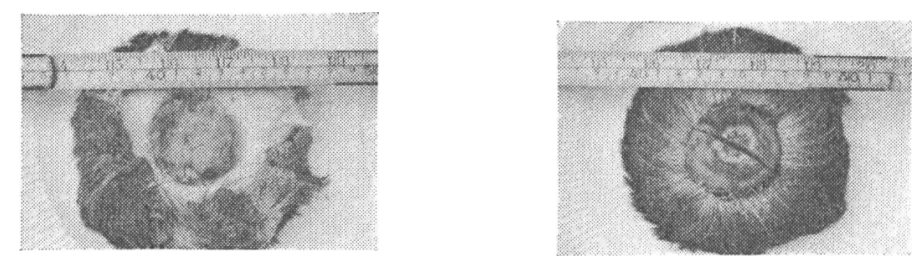

Figures 1 and 2. Malignant lymphoma. Skin. Reindeer.

homogenously grey. The brownish-grey area was limited to the outer $1 \mathrm{~mm}$ of the tumour. The prescapular lymph node was much enlarged, about $18 \times 9 \mathrm{~cm}$ in size. On the cut surface, greyish and brownish-red areas were observed. The liver and the muscle samples did not show any pathological changes.

Histology. The skin nodules consisted of masses of pleomorph reticular cells similar to histiocytes or macrophages. Lymphocytes were seen in some parts of the neoplasm. Mitoses occurred 
with some frequency. Fragmentation of nuclei and cell necrosis were also usual findings. The nodules were localized in dermis. Beneath the epidermis, the cells were more openly arranged. The overlying epidermis was thin, with minor infiltrations of inflammatory cells and cell fragments. In the neoplastic tissue, collagenous trabeculae and a loose reticular network were present. In some areas, small groups of cells were surrounded by thin reticular fibres (Figs. 3 and 4 ). In the prescapular lymph

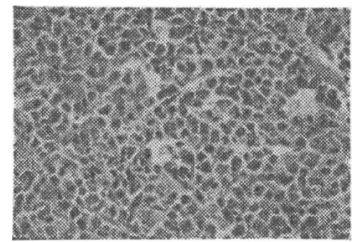

Figure 3. Malignant lymphoma. Skin. Reindeer. Haematoxylin-Eosin.

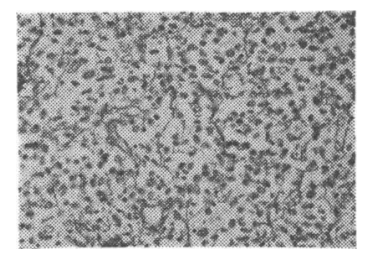

Figu re 4. Malignant lymphoma. Skin. Reindeer. Silver impregnation by Gomori.

node, the normal architecture was replaced by masses of cells of the same type as found in the skin nodule. Small necrotic areas, cell necroses and haemorrhages were also prominent features. The liver did not show any pathological changes.

\section{DISCUSSION}

A multiple cutaneous lymphoreticular tumour in reindeer is described. According to the classification by Smith et al. (1972) it should probably be classified as a malignant lymphoma of histocytic type. Metastases were found only in the prescapular lymph nodes. The animal was in good condition and did not show signs of clinical disease. The distribution of the tumour nodules in the skin corresponded to that of larvae of $O$. tarandi. However, no larvae were found in this particular animal, while the rest of the animals in the herd were infected as usual. This parasite is common in the reindeer population. All evidence indicates an association between larvae of $O$. tarandi and the multiple neoplasia described. The occurrence of true neoplasia in connection with parasite infestation has been reported (Smith et al.) In this case, the reaction to the larvae may be either one of inflammation or one of activation of reticular cells in a local immunological reaction with a pathological result. The latter is 
the most reasonable explanation in this case. The widespread occurrence of $O$.tarandi and the rare appearance of cutaneous neoplasms in reindeer indicates that animals which react in this way towards the larvae are very scarce in the herds. An explanation may also be that spontaneous resolution occurs in some cases, as can be the result in cases of reticuloendothelial skin tumours of other animals (Jubb \& Kennedy 1970). Extranodal occurrence of malignant lymphomas is thought to be quite unusual (Robbins \& Angell 1971).

\section{REFERENCES}

$J u b b, K . V . F . \&$ P. C. Kennedy: Pathology of Domestic Animals. 2nd Ed., Acad. Press. New York and London 1970. Vol. 2. 649 pp.

Robbins, S. L. \& M. Angell: Basic Pathology. W. B. Saunders Company. Philadelphia, London, Toronto 1971. $299 \mathrm{pp}$.

Smith, H. A., I. C. Jones \& R. C. Hunt: Veterinary Pathology. 4th Ed., Lea \& Febiger. Philadelphia 1972, 208-214.

\section{SAMMENDRAG}

Et tilfelle av multiple cutane maligne lymfomer av sannsynligvis immunologisk-parasittær årsak hos rein.

I en flokk reinsdyr som skulle slaktes $i$ februar 1977 i Finnmark hadde ett, ca $1 \frac{1}{2}$ år gammelt, dyr ca. 20 hårløse knuter på ryggen. Knutene var ca $5 \mathrm{~cm}$ i diameter, av regelmessig discoid fasong og velavgrenset. Knutene laget impresjoner $\mathrm{i}$ den underliggende muskulatur. De ble funnet å være nydannelser som tilsvarer maligne lymfomer, histiocyttær type (Smith et al. 1972). Metastaser ble påvist i de prescapulære lymfekjertler. Dyret var i alminnelig godt hold og viste ingen tegn på generell sykdom. Lokaliseringen av nydannelsene sammen med det faktum at det ikke ble påvist subcutane larver av reinens hudbrems (Oedemagena tarandi) hos dette dyret, gjør det rimelig å anta at nydannelsen er et resultat av en patologisk immunreaksjon.

(Received October 24, 1977).

Reprints may be requested from: Knut Kummeneje, State Veterinary Laboratory for Northern Norway, 9401 Harstad, Norway. 